\title{
A novel approach to evaluating water quality impacts on visitation to coastal recreation areas on Cape Cod using data derived from cell
}

\author{
phone locations.
}

[Short Title: Water quality and coastal visitation on Cape Cod, MA, USA]

Ryan P. Furey ${ }^{1,2}$, Nathaniel H. Merrill ${ }^{1}$, Josh P. Sawyer ${ }^{1,2}$, Kate K. Mulvaney ${ }^{1}$, Marisa J. Mazzotta ${ }^{1}$

${ }^{1}$ U.S. Environmental Protection Agency, Office of Research and Development, Center for Environmental Measurement and Modeling, Atlantic Coastal Environmental Sciences Division, Narragansett, Rhode Island, USA

2Oak Ridge Associated Universities (ORAU), Oak Ridge, Tennessee, USA

* Corresponding author

Email: furey.ryan@epa.gov (RF) 


\section{Abstract}

Linking human behavior to environmental quality is critical for effective natural resource management. While it is commonly assumed that environmental conditions partially explain variation in visitation to coastal recreation areas across space and time, scarce and inconsistent visitation observations challenge our ability to reveal these variations. With the ubiquity of mobile phone usage, novel sources of digitally derived data are increasingly available at a massive scale. Applications of mobile phone locational data have been effective in research on urban-centric human mobility and transportation, but little work has been conducted on understanding behavioral patterns surrounding dynamic natural resources. We present an application of cellphone locational data to estimate the effects of beach closures on visitation to coastal access points. Our results indicate that beach closures on Cape Cod, MA, USA have a significant negative correlation to visitation at those beaches with closures, while closures at a sample of coastal access points elsewhere in New England have no detected impact on visitation. Our findings represent geographic mobility patterns for over 7 million unique coastal visits and suggest that closures resulted in approximately $1,800(0.026 \%)$ displaced visits for Cape Cod during the summer season of 2017. We demonstrate the potential for human-mobility data derived from mobile phones to reveal the scale of use and behavior in response to changes in dynamic natural resources. Future applications of passively collected geocoded data to human-environmental systems are vast.

\section{Introduction}

Environmental degradation is increasingly recognized as having harmful social and economic consequences. Capturing the mode and magnitude of these consequences relies on measurement of human behavior, but the methods of measurement have constrained the ability to reveal the impacts of environmental quality [1,2]. Environmental characteristics like aesthetics and weather 
are commonly associated with influencing the demand for coastal recreation; however, the spatial heterogeneity of water resources combined with the lack of visitor counts for coastal access points makes the quantification of visitor behavior especially challenging $[3,4]$.

Degraded coastal water quality has become a pervasive issue and is an important factor in the availability and quality of coastal visits. To protect water quality for swimming purposes, coastal recreation waters in the United States are monitored seasonally for bacterial contamination and subsequently closed to swimming when levels surpass established thresholds. It has been demonstrated that closures can lead to economic and social losses for coastal communities [5-8] and that coastal recreation is sensitive to physical characteristics and changes in climactic conditions $[9,3]$. However, few studies have demonstrated the ability of environmental conditions to drive behavior across an entire region at high spatiotemporal resolution. This is largely because of the lack of large-scale, consistent, and ongoing visitation data collections. While effective, visual counts and surveys can be time-consuming and expensive, leading to work that is necessarily constrained across space and time and limited in reproducibility [10-12].

Passively collected geocoded data derived from cell phones provide the digital footprints of human activity. Using this form of data to study the spatiotemporal dynamics of human mobility has garnered considerable attention in recent years and is promising as a measurement instrument to assess the distribution of populations in space and time [10-11,13-16]. Cell data from a single service provider can quickly accumulate the activities of millions of people, especially in densely populated urban areas [17]. Newer forms of cell data are increasingly robust, as most cell phones contain GPS units that track locational data far more frequently than calls and texts are performed. This means that location data, in the form of latitude and longitude, are generated each time a device interacts with a network, which happens when a device connects to WiFi, GPS, Bluetooth, and mobile applications, in addition to calls or texts. Given the near universal adoption of mobile phones, cell data presents a compelling data source for investigating and understanding human 
mobility at a global scale, with much potential for understanding human interaction with natural resources $[14,18-20]$.

Cell data has been extensively used to analyze transportation infrastructure and commuting patterns [10,11], human mobility [21-24, 14, 16], transportation mode inference [25], and tourism dynamics and human behavior during special events [26-28]. Only a few studies have used cell data to understand human interaction with natural resources. Yu et al. [29] and Nyhan et al. [30-32] conducted some of the few examples of this type of study, using cell data to estimate exposure to ambient air pollution in urban areas. AirSage, in partnership with the U.S. Forest Service and National Park Service, piloted a project to assess monthly visitation to national forests and national parks using AirSage’s proprietary data [33]. Merrill et al. [13], Kubo et al. [34], and Monz et al. [35] provided the first uses of cell data to quantify visitation to natural areas across entire regions and for extensive timeframes. While these projects demonstrate the growing use of cell data for understanding general human mobility trends, there has yet to be research which employs cell data to analyze variations in human mobility patterns in response to changes in the quality of coastal resources. To date, no research has used cell data to investigate behavioral responses to water quality changes.

This paper presents an application of human-mobility data derived from mobile phone locations (hereafter referred to as cell data) to estimate the effects of beach closures on visitation to 565 coastal recreation areas in New England, USA, 465 of which are on Cape Cod, MA. Merrill et al. [13] demonstrated the viability of cell data to provide extensive and detailed visitation data to natural areas, showing how the data can replicate visitation estimates produced by observational counts, but with a much higher spatial and temporal resolution and larger geographic extent. Using a dataset derived from cell data which estimates visitation to 565 coastal recreation areas in New England across the summer season of 2017 (June-September), combined with EPA data on beach 
closures from bacterial contamination, this paper estimates visitation totals and the behavioral impacts of closures for coastal recreation areas on Cape Cod, MA, USA, as well as across New England. Our work demonstrates the potential for cell data to reveal behavioral patterns in response to a dynamic natural resource.

\section{Materials and Methods}

\section{Study Area}

Cape Cod is a peninsular land mass that protrudes into the Atlantic Ocean from Massachusetts' southeastern shoreline. The coastline is roughly 560 miles long and contains a range of water recreation areas from marine bathing beaches to estuarine waterways and inland ponds. These water recreation areas on Cape Cod are major attractions and provide significant ecosystem services for both visitors and residents alike [36]. The nature of water recreation in New England creates an element of significant seasonality; visitors flood to Cape Cod in the summer months, driving high rates of second-home ownership rates and residential dependence on a tourism-based economy. In 2015, the Cape Cod Commission estimated that roughly 5 million people visited Cape Cod, more than half of which were sometime between Memorial Day and Labor Day [37]. Given the significance of Cape Cod's water resources to both its seasonal visitors and permanent residents, beach closures from bacterial contamination are a primary concern for local and state environmental managers. While our research is primarily focused on Cape Cod, we include an additional analysis on a smaller sample of coastal recreation areas across the New England states of Maine, New Hampshire, Massachusetts, Rhode Island, and Connecticut. The purpose of this additional analysis was to test whether our results from Cape Cod were generalizable across a more diverse range of coastal recreation areas. 


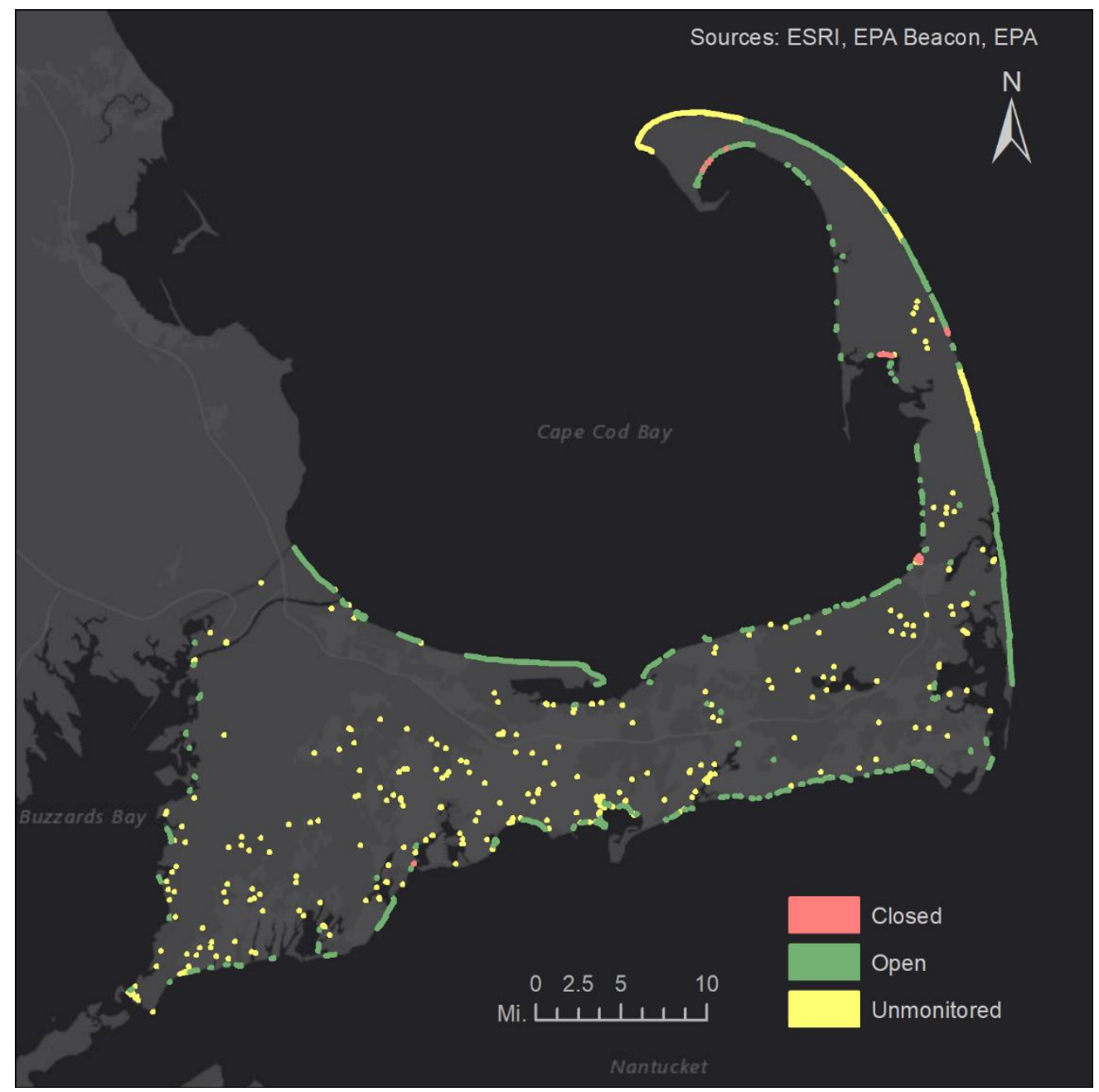

Fig 1. The comprehensive set of sampled water recreation areas on Cape Cod, Massachusetts. This includes all public ways to water, from inland freshwater ponds, to estuarine inlets, to large marine swimming beaches. Many of the coastal marine beaches are monitored for bacterial contamination, while freshwater ponds are unmonitored. Closed beaches refer to any beach that was closed, even once, during the summer in 2017.

\section{Data}

\section{Cell phone data}

We purchased cell data to estimate visitation for a comprehensive set of 465 public coastal access points on Cape Cod (Fig 1) during the summer season of 2017 (June, July, August, and September). 
Our sample of 465 coastal access points on Cape Cod represents all public ways to water which includes monitored and unmonitored freshwater and saltwater recreation areas. These recreation areas vary in type from small inland ponds to large coastal bathing beaches. Monitored recreation areas refer to coastal access points that were routinely (often weekly) examined for bacterial contamination by beach managers, municipalities, or state departments of health. We selected this complete set of public access points to maximize the opportunity for understanding variations in visitation within a socially and economically significant region with water quality concerns and to have comprehensive information for an entire region. Additionally, we purchased data for a set of 100 coastal access points with water quality monitoring histories in the New England states of Maine, New Hampshire, Massachusetts, Rhode Island, and Connecticut. The sample across New England's coastal states are a mix of saltwater beaches and public access points to saltwater areas that vary in size, type, recreational attributes, and water quality histories.

We purchased data from Airsage, Inc. Airsage is one of many companies that sells a range of data products derived from raw cell phone locations, which are collected by cellular service providers and application developers. The specific product provided to EPA by Airsage was developed using GPS locational information captured by smartphone applications. This data is then anonymized, cleaned, and packaged using proprietary methods to transform the raw cell data generated by smartphone application GPS information into anonymized estimates of visitation, which we aggregated into daily totals.

Through a comparison to a series of observational counts, Merrill et al. [13] determined that the cell data provided by Airsage overestimates the quantity of visitation to the specified geographic areas, especially when aiming to quantify visits that are uniquely recreational. Monz et al. [35] found that calibration of raw cell data was important for park areas in California, as Merrill et al. [13] did for water recreation areas in New England. The Airsage product used in this study was calibrated to observational visitation counts following the process described in Merrill et al. [13] to create daily 
visitation estimates to all coastal access areas for the duration of the study. Across the entire 2017 summer season, there were 7.5 million distinct visits to the 465 sampled coastal access points on Cape Cod (Fig 2), and 4.3 million visits to the sampled set of 100 coastal access points across New England.

Total Visits to Coastal Access Points on Cape Cod in 2017

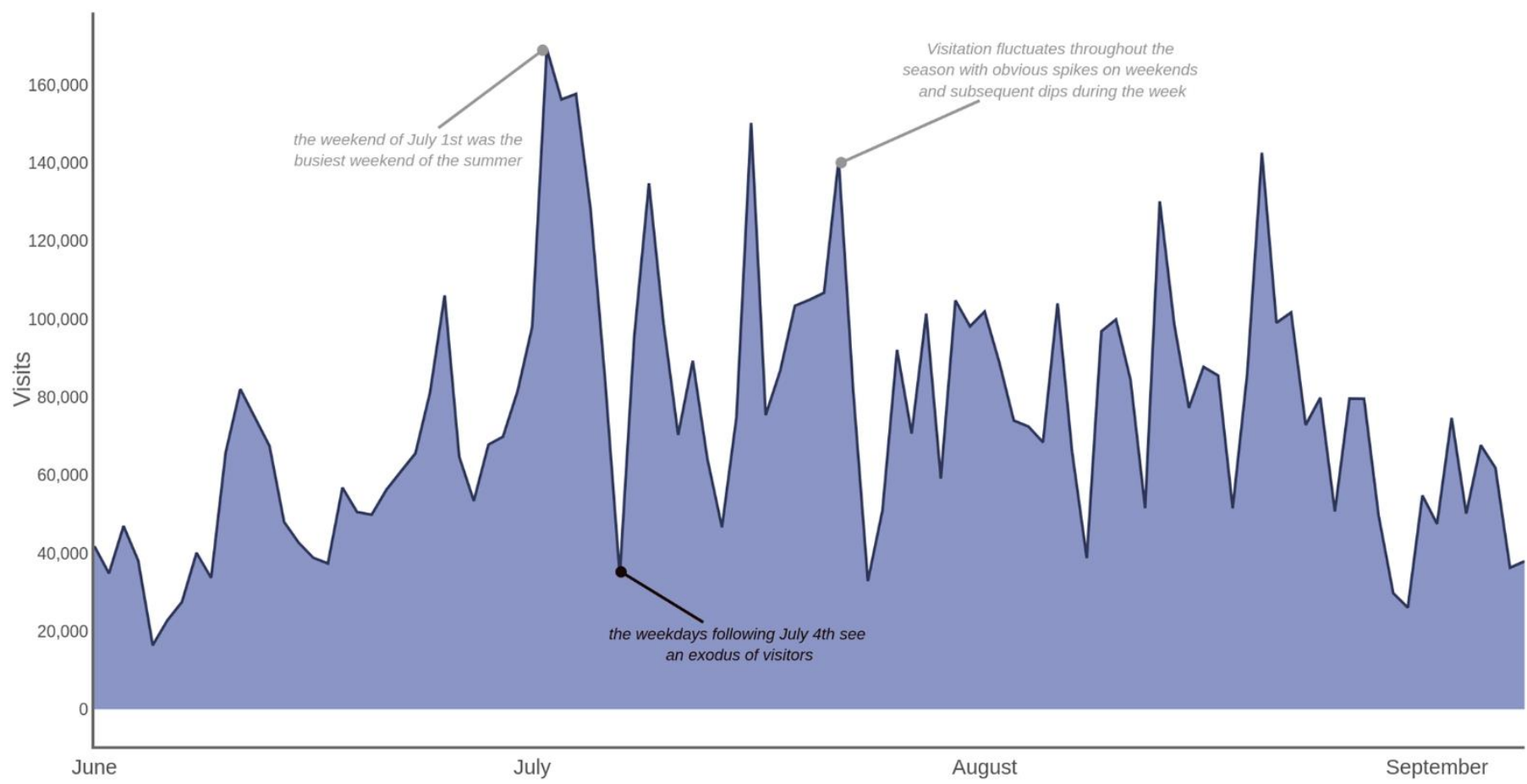

Fig 2. Total visits to the 465 coastal access points on Cape Cod in 2017.

\section{Beach closure data}

In the United States, non-point source pollution is the most common cause of contaminated water [38]. The specific causes of impairments vary based on location and waterbody type, but most coastal impairment listings are the result of pathogens, specifically bacterial contamination [39]. Bacterial contamination is typically from fecal sources, both point and non-point. The pathways 
through which these organisms travel are often sewage (leaking sewer pipes, combined sewer overflows, leaching septic systems, etc.), stormwater runoff, or human and animal waste discharged directly into the water. The bacterial pathogens that cause contaminated waters are directly linked to waterborne illnesses that are harmful to humans (such as gastrointestinal illness or respiratory illness) [39]. Given the risk posed to humans who are exposed to these pathogens, federal and state regulations require many coastal recreation areas (mainly popular state saltwater bathing beaches and select freshwater ponds) to be monitored for potential contamination.

The EPA's Beaches Environmental Assessment and Coastal Health (BEACH) Act of 2000 provides states with funding (through BEACH Act grants) to monitor their waterbodies for impairment [40]. The EPA is tasked with providing the data resulting from the states' monitoring efforts to the public. To do this, the EPA developed the Beach Advisory and Closing Online Notification (BEACON) system as a publicly accessible database [41] that aggregates states' beach monitoring data to a national scale. This resource provided the dataset that details 2017 beach closures in New England for our analysis. Beach closure data is readily available and reasonably consistent at a national scale, whereas other water quality measures are not.

On Cape Cod there were 173 water recreation areas monitored for bacterial contamination in 2017. Across the summer season, there were eight closure events at eight (5\%) recreation areas resulting in 20 closure days. There were over 800 coastal access points monitored for bacterial contamination across New England in 2017, 251 (nearly 30\%) of which were locations that either closed or posted advisories due to water quality testing results surpassing bacterial thresholds. The closures at these 251 locations resulted in 713 closure or advisory days across New England. Further detail on closures across New England is described in the supplementary information. 


\section{Weather data}

Our model also included a single set of weather parameters collected by the National Oceanic and Atmospheric Administration (NOAA) at the Hyannis, Barnstable Municipal-Boardman Airport weather station which is located centrally on Cape Cod and representative of the weather conditions across our sample locations. NOAA provides daily summaries of precipitation, windspeed, and temperature, which we accessed and downloaded through NOAA's online weather data download portal [42].

\section{Model}

To understand how closures due to impaired water quality affect visits to New England coastal recreation areas, we developed a model that explains the variation in daily visitation to our set of 565 New England coastal access points. Once a representative model was established, we could then interrogate what effect, if any, closures have on visitation to these coastal access points. The closure dataset was incorporated into the behavioral model to determine if closures were significant in explaining the variation in visitation across the 2017 summer season conditional on other factors influencing visitation.

The unique size and structure of the visitation data, which includes 51,511 daily visitation estimates, allowed us to apply a panel regression model to understand which factors explain coastal visitation. Taking advantage of the panel structure of our data (location of interest $\mathrm{x}$ days), we created a fixed effects regression model to estimate daily visitation as a function of a set of explanatory variables and a coastal access point specific constant:

$$
Y_{i t}=\alpha_{i}+\boldsymbol{\beta}_{W} \boldsymbol{W}_{\boldsymbol{t}}+\boldsymbol{\beta}_{\boldsymbol{M}} \boldsymbol{M}_{t}+\boldsymbol{\beta}_{\boldsymbol{D}} \boldsymbol{D}_{t}+\boldsymbol{\beta}_{\boldsymbol{H}} \boldsymbol{H}_{t}+\beta_{C} C_{i t}+e_{i t}
$$

where, $Y_{i t}$ - visits to coastal access point $i$ on day $t$

$\alpha_{i}$ - intercept for each coastal access point $i$ 
$\boldsymbol{\beta}_{\boldsymbol{W}} \boldsymbol{W}_{\boldsymbol{t}}$ - vector product of coefficient $\boldsymbol{\beta}_{\boldsymbol{W}}$ and daily weather conditions $\boldsymbol{W}_{t}$ (temperature, precipitation, and rainy-day dummy variable)

$\boldsymbol{\beta}_{\boldsymbol{M}} \boldsymbol{M}_{t}$ - vector product coefficient $\boldsymbol{\beta}_{\boldsymbol{M}}$ and month dummy variables $\boldsymbol{M}_{t}$ $\boldsymbol{\beta}_{\boldsymbol{D}} \boldsymbol{D}_{t}$ - vector product of coefficient $\boldsymbol{\beta}_{\boldsymbol{D}}$ and day of the week dummy variables $\boldsymbol{D}_{t}$ $\boldsymbol{\beta}_{\boldsymbol{H}} \boldsymbol{H}_{t}$ - vector product of coefficient $\boldsymbol{\beta}_{\boldsymbol{H}}$ and dummy variables for weekends (including holiday weekends) $\boldsymbol{H}_{t}$

$\beta_{C} C_{i t}$ - product of coefficient $\beta_{C}$ and dummy variable for each day $t$ a beach $i$ had a closure posted $C_{i t}$

$e_{i t}$ - within beach error term

A fixed effect specification controls for any non-time-varying attributes of the coastal recreation areas and points of interest, such as site size, facilities and any other non-varying environmental and site quality features [43]. While the specification controls for these factors in estimating the other marginal effects of interest, it did not allow us to distinguish the individual effect of these non-time varying factors on visitation. Our water quality attribute of interest varied over time, as a time series of open or closed statuses for each coastal access point.

We specified different functional forms of the model: linear, log-linear and log-log. We inferred that all the covariates, such as weather or day of the week, would not explain visitation linearly across differently sized or types of locations, meaning the effect of changes in covariates were not additive but more likely multiplicative. Based on this logic and the structure of the errors post estimation, we chose a log-linear regression model, which fit the data best. A percent change in visitation $(Y)$ resulting from a change in one of the explanatory variables, holding all others constant, was calculated as $100 \bullet\left(e^{\beta_{i}-1}\right)$. Therefore, the coefficient on the dummy variable describing whether a coastal recreation area was open or closed can be interpreted as roughly the percent fewer people visiting the access point that day than would have been visiting with no closure.

We ran the regression described above for the set of coastal access points on Cape Cod $(n=465)$ [45]. In addition, considering the diverse physical and spatial characteristics of the access points in our sample, we elected to stratify the sample into categories (Fig 3) to test two hypotheses: 1. 
assuming variation in physical and spatial characteristics drives differences in visitor type (and therefore recreational use type), our model would likely explain visitation differently for various categories of water recreation areas; and 2. given the variation in visitation type, we would also expect to capture closures' effect differently for these categories. So, in addition to running the regression on the sample set for Cape Cod, we also ran the regression on spatially large access points on Cape Cod ( $3^{\text {rd }}$ quartile area $\left.\mathrm{m}^{2}, \mathrm{n}=185\right)$ and on only access points monitored by the Barnstable County Department of Health and Environment for bathing beach quality (bacteria) on Cape Cod (n=174). Lastly, to investigate how

generalizable the results are to access points across New England we also ran the regression on a set of 100 water recreation areas across New England (i.e., off-Cape access points). 

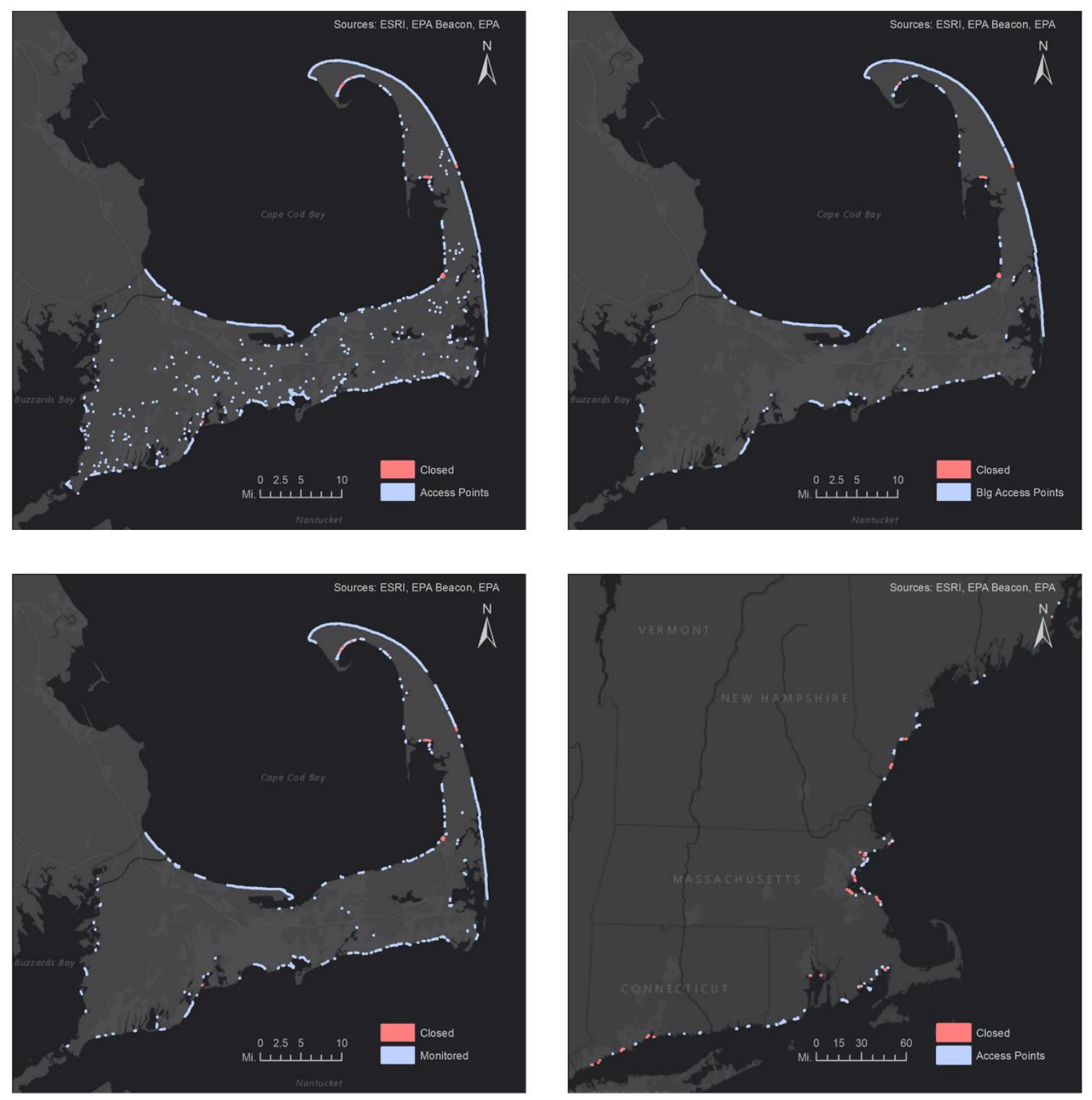

Fig 3. The four groupings of access points by category. We ran regressions on each set of coastal access points consisting of (clockwise from top left) all Cape Cod access points $(n=465)$, all large Cape Cod access points ( $3^{\text {rd }}$ quartile area $\mathrm{m}^{2}, n=185$ ), all off-Cape access points, and all monitored Cape access points $(n=174)$. Access points with closures in 2017 are indicated in red. 


\section{Results}

Results from our models can be seen in Table 1 and in the expanded results in the supplementary information. Our initial regression included the entire set of 465 access points on Cape Cod across the summer season of 2017. Daily precipitation and temperature had a substantial effect on visitation, with one centimeter of precipitation reducing estimated visitation by 21 percent and an increase in one-degree centigrade resulting in an eight percent increase. Daily average wind speed (wind), and dummies for months and days of the week were also significant in affecting visitation.

\begin{tabular}{|c|c|c|c|c|}
\hline \multicolumn{5}{|c|}{ Dependent variable: Log of visits } \\
\hline & $\begin{array}{c}\text { All Cape Access } \\
\text { Points }\end{array}$ & $\begin{array}{c}\text { Big Cape Access } \\
\text { Points }\end{array}$ & $\begin{array}{c}\text { Monitored Cape } \\
\text { Access Points }\end{array}$ & $\begin{array}{c}\text { Off Cape Access } \\
\text { Points }\end{array}$ \\
\hline \multirow[t]{2}{*}{ Temperature } & $0.080^{* * *}$ & $0.100^{* * *}$ & $0.097^{* * *}$ & $0.090^{* * *}$ \\
\hline & $(0.001)$ & $(0.002)$ & $(0.001)$ & $(0.002)$ \\
\hline \multirow[t]{2}{*}{ Wind } & $0.004^{* * *}$ & -0.003 & -0.001 & $0.005^{*}$ \\
\hline & $(0.001)$ & $(0.002)$ & $(0.002)$ & $(0.002)$ \\
\hline \multirow[t]{2}{*}{ Precipitation } & $-0.217^{* * *}$ & $-0.274^{* * *}$ & $-0.112^{* * *}$ & $-0.100^{* * *}$ \\
\hline & $(0.010)$ & $(0.020)$ & $(0.003)$ & $(0.004)$ \\
\hline \multirow[t]{2}{*}{ June } & $-0.217^{* * *}$ & $-0.274^{* * *}$ & $-0.263^{* * *}$ & $-0.167^{* * *}$ \\
\hline & $(0.010)$ & $(0.020)$ & $(0.016)$ & $(0.021)$ \\
\hline \multirow[t]{2}{*}{ July } & $-0.140^{* * *}$ & $-0.145^{* * *}$ & $-0.120^{* * *}$ & $-0.089 * * *$ \\
\hline & $(0.011)$ & $(0.023)$ & $(0.019)$ & $(0.024)$ \\
\hline \multirow[t]{2}{*}{ August } & $-0.226^{* * *}$ & $-0.238^{* * *}$ & $-0.230^{* * *}$ & $-0.192^{* * *}$ \\
\hline & $(0.011)$ & $(0.023)$ & $(0.018)$ & $(0.023)$ \\
\hline \multirow[t]{2}{*}{ Tuesday } & $-0.034^{* * *}$ & $-0.062^{* * *}$ & $-0.068^{* * *}$ & $-0.032 *$ \\
\hline & $(0.009)$ & $(0.018)$ & $(0.014)$ & $(0.019)$ \\
\hline \multirow[t]{2}{*}{ Wednesday } & $0.074^{* * *}$ & $0.170^{* * *}$ & $0.105^{* * *}$ & $0.116^{* * *}$ \\
\hline & $(0.010)$ & $(0.020)$ & $(0.016)$ & $(0.021)$ \\
\hline \multirow[t]{2}{*}{ Thursday } & $0.042^{* * *}$ & $0.028^{*}$ & -0.003 & 0.018 \\
\hline & (0.009) & $(0.017)$ & $(0.014)$ & $(0.018)$ \\
\hline \multirow[t]{2}{*}{ Friday } & $0.095^{* * *}$ & $0.103^{* * *}$ & $0.102^{* * *}$ & $0.131^{* * *}$ \\
\hline & $(0.009)$ & $(0.018)$ & $(0.014)$ & $(0.019)$ \\
\hline \multirow[t]{2}{*}{ Saturday } & $0.263^{* * *}$ & $0.273^{* * *}$ & $0.278^{* * *}$ & $0.263^{* * *}$ \\
\hline & $(0.010)$ & $(0.020)$ & $(0.016)$ & $(0.020)$ \\
\hline \multirow[t]{2}{*}{ Sunday } & $0.316^{* * *}$ & $0.415^{* * *}$ & $0.386^{* * *}$ & $0.447^{* * *}$ \\
\hline & $(0.009)$ & $(0.018)$ & $(0.014)$ & (0.019) \\
\hline \multirow[t]{2}{*}{ Closed } & $-0.164^{* *}$ & $-0.253^{* *}$ & $-0.180^{* *}$ & 0.015 \\
\hline & $(0.074)$ & & $(0.083)$ & $(0.027)$ \\
\hline Observations & 29,141 & 8,565 & 13,360 & 8,196 \\
\hline $\mathrm{R}^{2}$ & 0.49 & 0.55 & 0.533 & 0.510 \\
\hline Adjusted $\mathrm{R}^{2}$ & 0.478 & 0.538 & 0.526 & 0.503 \\
\hline
\end{tabular}




\begin{tabular}{lcccc} 
& $1,179.208^{* * *}$ & $439.217^{* * *}$ & $653.605^{* * *}$ & $365.458^{* * *}$ \\
F Statistic & $(\mathrm{df}=23 ;$ & $(\mathrm{df}=23 ; 8437)$ & $(\mathrm{df}=23 ;$ & $13164)$ \\
& $28701)$ & & $(\mathrm{df}=23 ; 8073)$ \\
\hline \hline
\end{tabular}

Note: Regressions include fixed effects for each beach. The effect of beach closures is significant for the Cape beaches and more-so for larger beaches over $56,926 \mathrm{~m}^{2}$ in size. Each fixed effect regression contains lags of visitation for 10 days to correct for serial correlation in the error term.

TABLE 1. Fixed Effect Regressions for Beach Closures

When executing the regression for all Cape Cod access points, spatially large access points on Cape Cod, and monitored access points on Cape Cod, the closure variable was negative and significant $(\mathrm{p}<0.01)$. According to our model, a closure at any Cape Cod access point would reduce visitation to that location by 16.4 percent for that day, while a closure at a large access point on Cape Cod would reduce visitation by 25.3 percent, and a closure at any monitored access point would reduce visits by 18 percent. In 2017, there were eight coastal access points that had closures from bacterial contamination resulting in 20 days closed to water-based activities. This resulted in approximately 1,800 lost visits for these access points across 20 closure days in the season, shown as the lighter shaded area below the dotted line in Fig 4. 


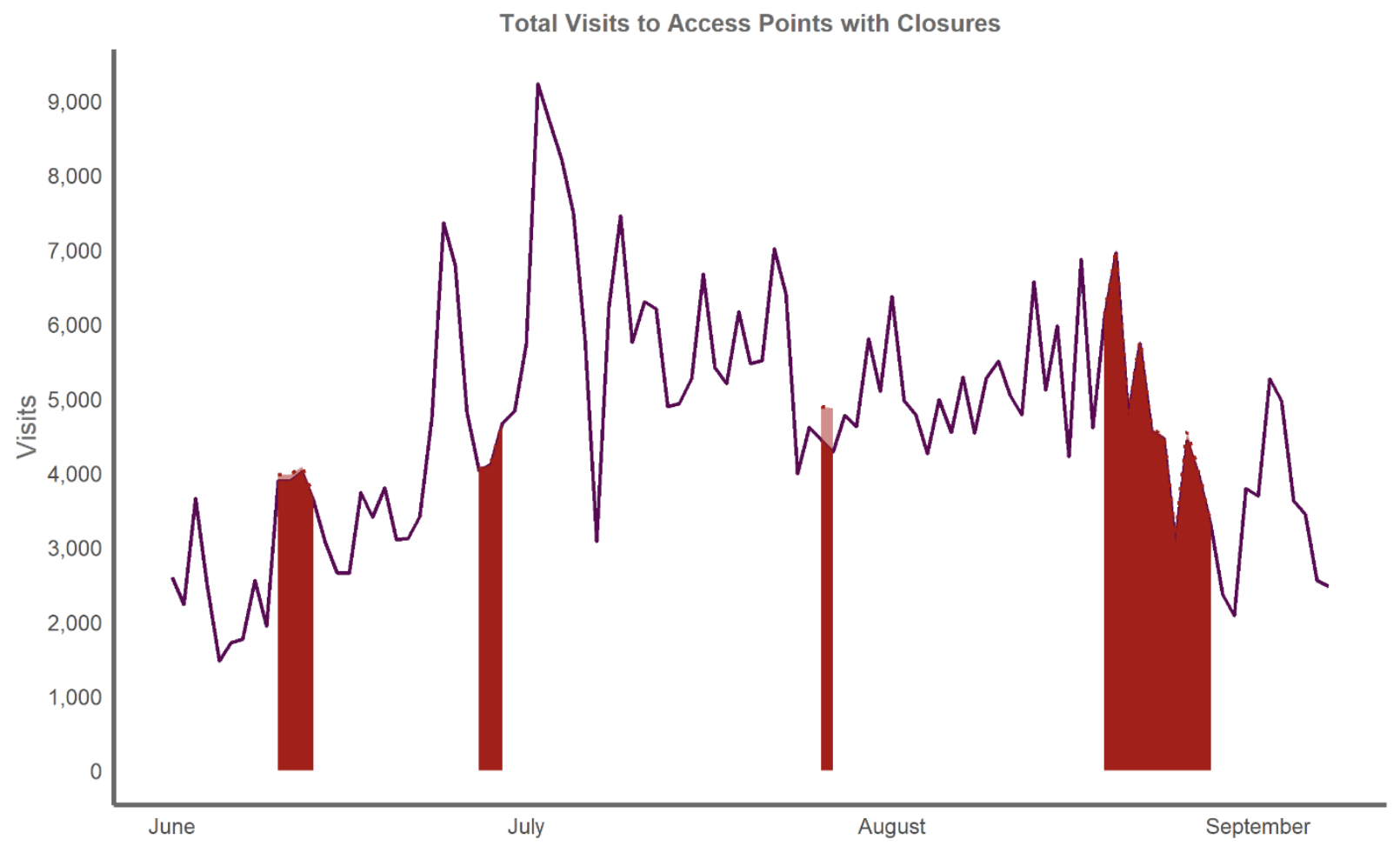

Fig 4. Total visits to Cape Cod access points with at least 1 closure in 2017. Red areas beneath the line represent date ranges that have at least one closed beach. We project the total visits if there was not a closure in light red, but the difference is quite small except for the closure in late July.

Closure events vary in duration and geographic effect. Looking at individual beaches illuminates the varying effects of closures. Certain events, like the closure at Dyer Street Beach (Fig 5), closed the recreation area for four days, but the closure was isolated to the single beach. Other closure events were minimal in duration, like the event on July 26 and 27,2017, but affect groups of access points as opposed to isolated locations likely due to regionally high rainfall and runoff events (Fig 6). 


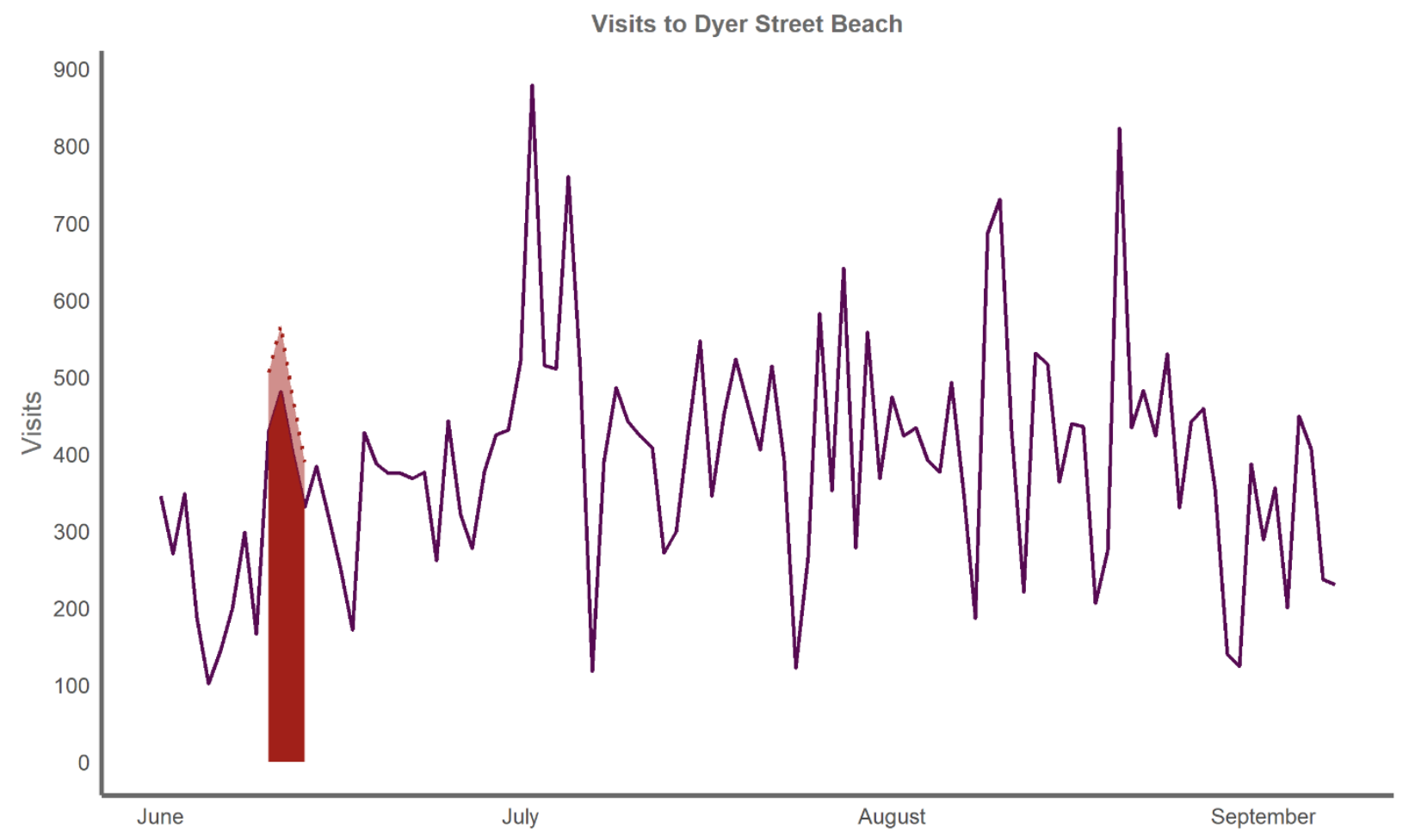

Fig 5. Visits to Dyer Street beach in 2017. The dark red area beneath the line shows the range of dates when the beach was closed. We project the total visits if there was not a closure (i.e., lost visits) in light red below the dotted line. 

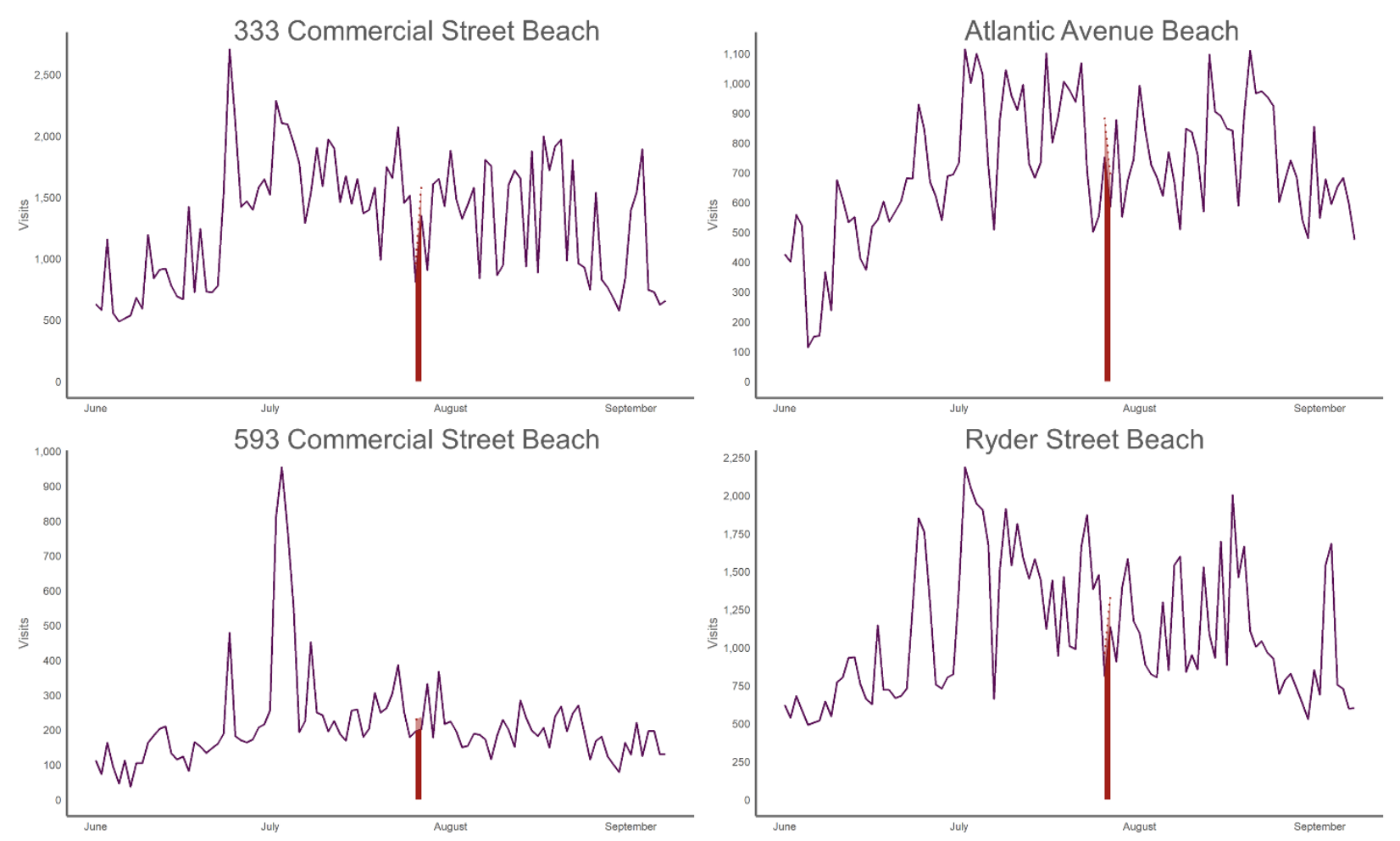

Fig 6. Seasonal total visits to 333 Commercial Beach, Atlantic Avenue Beach, Ryder Street Beach, and 593 Commercial Street Beach. Highlighted in red is the July 26 and 27 closure that impacted all four of these beaches. These four simultaneous closure events resulted in the most displaced visits in 2017 of all closure events and were likely directly tied to the same specific rain event.

Despite the closures being significant and negative for coastal access points on Cape Cod, this result did not generalize to our sample of 100 coastal access points across New England. While there is certainly room to improve upon our model of visitation to more accurately estimate the variation in visitation at each beach, there are several other reasons why effects of closures may not have been detected when running the regression on that set of 100 coastal access points across New England. The beaches where we detected the effect of a closure historically close less frequently (0.4 days per year on average in the last five years for monitored beaches on Cape Cod). Locations that had closures in 2017 where closures were not detected as a significant driver of variation in visitation on average close more often (3.3 days per year on average in the last five years for the set of 100 
coastal recreation areas across New England). Certain locations like Wollaston Beach, MA, had fiveyear closure averages surpassing 30 days annually. We hypothesize that for beaches where closures were detected as significant, the closure was a rarity and resulted in more disruption of assumed quality and swimming activities. For beaches where closures were more frequent, a closure might not have affected the plans of those individuals visiting because the intended activities were not water-based or did not involve direct water contact. Furthermore, those visiting beaches with historically frequent closures may have been aware of that beach's closure reputation and planned their water-contact accordingly. It is difficult to prove this using cell data alone, as there is no straightforward way to stratify visits by activity type.

Another critical driver of our ability to detect the impact of closures on visitation is the closure dataset itself. While the dataset provides a crucial indicator of water quality at a national scale, the nuances of beach closures vary at the regional, state, and municipal levels. Certain states (like Maine, New Hampshire, and Rhode Island) post "advisories" that are suggestions to beach-goers to avoid contact with water. These states' laws contain provisions where beach postings are the responsibility of local jurisdictions [45]. Other states (such as Massachusetts) have it written into law that swimming or bathing are prohibited when water quality does not meet requirements [46]. In New Hampshire and Maine, local beach managers and boards of health retain the right to keep a beach open or state a beach is closed using their own discretion [45, 47]. Across New England, beach closures and swimming advisories do not prohibit the use of a beach for land-based activities (walking, sports, etc.) [48]. Additionally, the methods of sampling and testing water quality often take at minimum 24 hours to process, creating a potential delay between the beach closure and the quality event. The aggregation of this ambiguity in the mechanisms employed to close a given beach create practical challenges to using beach closures as a proxy for water quality.

One of the benefits of using more comprehensive datasets of visitation to water recreation areas, as in this study, is quantifying the total use and the number trips protected by town, regional, and 
state health departments sampling and closure programs. For Cape Cod, the monitoring program was protective of 4.2 million trips in one summer alone. As coastal recreation continues to grow in its economic influence and cultural value, so should the efficacy of these methods and the funding that is allocated to the organizations responsible for performing them.

\section{Discussion}

This study used cell data to estimate the effects of closures on visitation to coastal access points on Cape Cod and in New England, USA for the summer season of 2017. Using a model of daily visitation combined with the dataset on bacterial closures, we were able to detect the impact of closures for coastal access points on Cape Cod. Our findings represent geographic mobility patterns for over 7 million unique visits and suggest that beach closures resulted in approximately 1,800 displaced visits on Cape Cod beaches during the summer season of 2017. However, we were unable to detect this effect for our broader New England sample.

Although there has been significant progress made towards understanding the biological and physical implications of water quality degradation, capturing both market and non-market damages of pollution, especially for water quality degradation, has remained a challenge for researchers. Linking changes in environmental systems to socioeconomic, behavioral, and human health outcomes is a crucial step in valuing the benefits of scientific progress and assessing the damages of environmental degradation [49]. In order to accomplish this, it is necessary to develop methods that reveal the scale of use and behavior in response to changes in dynamic natural resources. As coastal recreation is increasingly recognized as a primary driver of economic activity both across New England and nationally [50], accurate visitation estimates are crucial in enabling these novel research methodologies to advance [12]. 
Cell data offers a promising tool in approaching and resolving spatiotemporal mobility problems in the environmental sciences. Whereas the use of cell data for investigating human interaction with natural resources is still emerging as a body of literature, the last decade has seen substantial growth in volume and velocity of geographically coded data products [19]. With the growing availability of this type of data, many applications complementary to ours are appearing within social sciences research, urban planning, and public health [32, 33, 35]. As these data types become more accessible and accurate, so will the ability of researchers to open new lines of inquiry and derive novel understanding of human-environmental systems.

Despite its promise as an instrument for measuring human behavior around natural resources, cell data is not a panacea. The utility in a spatiotemporally resolved dataset like that provided by mobile devices is in its ability to understand the what (and sometimes how) of a sample population's behavior. However, it does little to help with understanding the motivations behind decision making. To capture this, traditional field-based methods of social science are still required. Evaluated independently, cell data lack nuance and context, leading to premature and one-size-fitsall assumptions. Instead, employing methods of research that reveal motivations are more necessary than ever. Used in concert with novel data approaches, researchers, policymakers, and natural resource managers can overcome barriers to making targeted, effective, and user-centric decisions. 


\section{Acknowledgements}

The views expressed in this article are those of the authors and do not necessarily represent the views or policies of the U.S. Environmental Protection Agency. This contribution is identified by the tracking number ORD-038121 of the Atlantic Coastal and Environmental Sciences Division, Center for Environmental Measurement and Modeling, Office of Research and Development, U.S. Environmental Protection Agency. We would like to thank Wei-Lun Tsai, Jessica Daniel, and Hale Thurston for their thoughtful reviews.

\section{References}

1. Mulvaney KK, Atkinson SF, Merrill NH, Twichell JH, Mazzotta MJ. Quantifying Recreational Use of an Estuary: A Case Study of Three Bays, Cape Cod, USA. Estuaries and Coasts. 2020 Jan 1;43(1):7-22. National Marine Fisheries Service (US), editor. Fisheries economics of the United States, 2012. Government Printing Office; 2014 Sep 23.

2. De Cantis S, Parroco AM, Ferrante M, Vaccina F. Unobserved tourism. Annals of Tourism Research. 2015 Jan 1;50:1-8.

3. Coombes EG, Jones AP, Bateman IJ, Tratalos JA, Gill JA, Showler DA, Watkinson AR, Sutherland WJ. Spatial and temporal modeling of beach use: a case study of East Anglia, UK. Coastal Management. 2009 Jan 21;37(1):94-115.

4. Coombes EG, Jones AP. Assessing the impact of climate change on visitor behaviour and habitat use at the coast: A UK case study. Global environmental change. 2010 May 1;20(2):303-13.

5. Lyon, S. F., Merrill, N. H., Mulvaney, K. K., \& Mazzotta, M. J. (2018). Valuing Coastal Beaches and Closures Using Benefit Transfer: An Application to Barnstable, Massachusetts. Journal of ocean and coastal economics, 5(1), 1-1. 
6. Kreitler J, Papenfus M, Byrd K, Labiosa W. Interacting coastal based ecosystem services: recreation and water quality in Puget Sound, WA. PloS one. 2013 Feb 22;8(2):e56670.

7. Hanley N, Bell D, Alvarez-Farizo B. Valuing the benefits of coastal water quality improvements using contingent and real behaviour. Environmental and resource economics. 2003 Mar $1 ; 24(3): 273-85$.

8. Deacon RT, Kolstad CD. Valuing beach recreation lost in environmental accidents. Journal of Water Resources Planning and Management. 2000 Dec;126(6):374-81.

9. Patrolia E, Thompson R, Dalton T, Hoagland P. The influence of weather on the recreational uses of coastal lagoons in Rhode Island, USA. Marine Policy. 2017 Sep 1;83:252-8.

10. Kung KS, Greco K, Sobolevsky S, Ratti C. Exploring universal patterns in human home-work commuting from mobile phone data. PloS one. 2014 Jun 16;9(6):e96180.

11. Toole JL, Ulm M, González MC, Bauer D. Inferring land use from mobile phone activity. In Proceedings of the ACM SIGKDD international workshop on urban computing 2012 Aug 12 (pp. 1-8). ACM.

12. English D, Bowker JM. Introduction to the Special Issue on Visitor Monitoring. Journal of Park and Recreation Administration. 2018;36(1).

13. Merrill N, Atkinson SF, Mulvaney KK, Mazzotta MJ, Bousquin J. Using Data Derived from Cellular Phone Locations to Estimate Visitation to Natural Areas: An Application to Water Recreation in New England, USA. 2019. arXiv preprint, arXiv doi:10.31235/osf.io/3nx2v.

14. Eagle N, Pentland AS. Reality mining: sensing complex social systems. Personal and ubiquitous computing. 2006 May 1;10(4):255-68.

15. Raento M, Oulasvirta A, Eagle N. Smartphones: An emerging tool for social scientists. Sociological methods \& research. 2009 Feb;37(3):426-54.

16. Song C, Qu Z, Blumm N, Barabási AL. Limits of predictability in human mobility. Science. 2010 Feb 19;327(5968):1018-21. 
17. Toole JL, Colak S, Sturt B, Alexander LP, Evsukoff A, González MC. The path most traveled: Travel demand estimation using big data resources. Transportation Research Part C: Emerging Technologies. 2015 Sep 1;58:162-77.

18. Poushter J. Smartphone ownership and internet usage continues to climb in emerging economies. Pew Research Center. 2016 Feb 22;22:1-44.

19. Ford JD, Tilleard SE, Berrang-Ford L, Araos M, Biesbroek R, Lesnikowski AC, MacDonald GK, Hsu A, Chen C, Bizikova L. Opinion: Big data has big potential for applications to climate change adaptation. Proceedings of the National Academy of Sciences. 2016 Sep 27;113(39):10729-32.

20. Blondel VD, Decuyper A, Krings G. A survey of results on mobile phone datasets analysis. EPJ Data Science. 2015 Dec;4(1):10.

21. Kondor D, Grauwin S, Kallus Z, Gódor I, Sobolevsky S, Ratti C. Prediction limits of mobile phone activity modelling. Royal Society open science. 2017 Feb 1;4(2):160900.

22. Zhang D, Zhao J, Zhang F, He T. comobile: Real-time human mobility modeling at urban scale using multi-view learning. InProceedings of the 23rd SIGSPATIAL International Conference on Advances in Geographic Information Systems 2015 Nov 3 (p. 40). ACM.

23. Hasan S, Schneider CM, Ukkusuri SV, González MC. Spatiotemporal patterns of urban human mobility. Journal of Statistical Physics. 2013 Apr 1;151(1-2):304-18.

24. Gonzalez MC, Hidalgo CA, Barabasi AL. Understanding individual human mobility patterns. nature. 2008 Jun;453(7196):779.

25. Wang H, Calabrese F, Di Lorenzo G, Ratti C. Transportation mode inference from anonymized and aggregated mobile phone call detail records. In13th International IEEE Conference on Intelligent Transportation Systems 2010 Sep 19 (pp. 318-323). IEEE.

26. Leng Y, Noriega A, Pentland AS, Winder I, Lutz N, Alonso L. Analysis of tourism dynamics and special events through mobile phone metadata. arXiv preprint, arXiv:1610.08342. 2016 Oct 26. 
27. Dong Y, Pinelli F, Gkoufas Y, Nabi Z, Calabrese F, Chawla NV. Inferring unusual crowd events from mobile phone call detail records. InJoint European conference on machine learning and knowledge discovery in databases 2015 Sep 7 (pp. 474-492). Springer, Cham.

28. Calabrese F, Pereira FC, Di Lorenzo G, Liu L, Ratti C. The geography of taste: analyzing cellphone mobility and social events. International conference on pervasive computing 2010 May 17 (pp. 22-37). Springer, Berlin, Heidelberg.

29. Yu H, Russell A, Mulholland J, Huang Z. Using cell phone location to assess misclassification errors in air pollution exposure estimation. Environmental pollution. 2018 Feb 1;233:261-6.

30. Nyhan M, Grauwin S, Britter R, Misstear B, McNabola A, Laden F, Barrett SR, Ratti C. “Exposure Track" The Impact of Mobile-Device-Based Mobility Patterns on Quantifying Population Exposure to Air Pollution. Environmental science \& technology. 2016a Aug 24;50(17):9671-81.

31. Nyhan M, Sobolevsky S, Kang C, Robinson P, Corti A, Szell M, Streets D, Lu Z, Britter R, Barrett SR, Ratti C. Predicting vehicular emissions in high spatial resolution using pervasively measured transportation data and microscopic emissions model. Atmospheric environment. 2016b Sep 1;140:352-63.

32. Nyhan MM, Kloog I, Britter R, Ratti C, Koutrakis P. Quantifying population exposure to air pollution using individual mobility patterns inferred from mobile phone data. Journal of exposure science \& environmental epidemiology. 2019 Mar;29(2):238.

33. Sivaraman, V., Gandavarapu, S. \& Sabba, K. Estimating monthly visitation to U.S. national forests and national parks from mobile phone activities. TRB2016 Washington, DC, Transportation Research Board. 2016. Available from: http://www.trbcensus.com/TRB2016/poster/Sivaraman_Visitations_poster_TRB2016.pdf

34. Kubo T, Uryu S, Yamano H, Tsuge T, Yamakita T, Shirayama Y. Mobile phone network data reveal nationwide economic value of coastal tourism under climate change. Tourism Management. 2020 Apr 1;77:104010. 
35. Monz C, Mitrovich M, D'Antonio A, Sisneros-Kidd A. Using Mobile Device Data to Estimate Visitation in Parks and Protected Areas: An Example from the Nature Reserve of Orange County, California. Journal of Park and Recreation Administration. 2019;37(4).

36. Kline JD, Swallow SK. The demand for local access to coastal recreation in southern New England. Coastal Management. 1998 Jan 1;26(3):177-90.

37. Cape Cod Commission. Cape Cod area wide water quality management plan update. Last updated June. 2015;15:2015.

38. US Environmental Protection Agency (USEPA). National water quality inventory: 2000 Report.

39. Lindberg K. Municipal Guide to Clean Water: Conducting Sanitary Surveys to Improve Coastal Water Quality. 2010.

40. Assessment BE. Coastal Health Act. 2000. Public law. 2000:106-284.

41. U.S. EPA. BEACON 2.0 (Beach Advisory and Closing Online Notification); 2020 [cited 2020 Jan 16]. Database: BEACON [Internet]. Available from: https://www.epa.gov/waterdata/beacon20-beach-advisory-and-closing-online-notification.

42. National Oceanic and Atmospheric Administration, National Centers for Environmental Information. 2020 [cited 2020 March 10]. Database: Daily Summaries Station Details [Internet]. Available from: https://www.ncdc.noaa.gov/cdoweb/datasets/GHCND/stations/GHCND:USW00094720/detail

43. Greene WH. Econometric analysis. Pearson Education India; 2003.

44. Kaczor K, Sims M. Maine Healthy Beaches 2014 Report to US EPA. Maine Sea Grant Publications. 41.Available from: https://digitalcommons.library.umaine.edu/seagrant_pub/41

45. R Core Team. 2020 [cited 2020 March 10]. R: a language and environment for statistical computing. 
46. Department of Public Health (DPH) M. 105 CMR 445.000: Minimum Standards For Bathing Beaches, State Sanitary Code, Chapter VII. Massachusetts Department of Public Health, Division of Community Sanitation Regulations and Statutes, Boston, MA. Retrieved. 2002 Sep;19.

47. New Hampshire Department of Environmental Services. [cited 15 January 2020]. In: NH DES [Internet]. Available from: https://www.des.nh.gov/organization/divisions/water/wmb/beaches/advisories.htm.

48. Barnstable County Department of Health and Environment (BCDHE). [cited 9 March 2020]. In: BCDHE FAQ's [Internet]. Available from: https://www.barnstablecountyhealth.org/programsand-services/bathing-beach-water-quality/frequently-asked-questions

49. Burke M, Craxton M, Kolstad CD, Onda C, Allcott H, Baker E, Barrage L, Carson R, Gillingham K, Graff-Zivin J, Greenstone M. Opportunities for advances in climate change economics. Science. 2016 Apr 15;352(6283):292-3.

50. Bureau of Economic Analysis (BEA). Outdoor Recreation Satellite Account, U.S. and Prototype for States, 2017: New prototype statistics show state value added, compensation, and employment. 2019; 1: 56. Available from: https://www.bea.gov/system/files/201909/orsa0919 1.pdf. 